\title{
Kedudukan Hukum Pihak Ketiga dalam Layanan Keuangan Tanpa Kantor
}

\author{
Leli Joko Suryono, Reni Anggriani
}

DATA NASKAH:

Masuk: 15 Juni 2018

Diterima: 10 September 2018

Terbit: 31 Desember 2018

KORESPONDEN PENULIS:

Fakultas Hukum, Universitas

Muhammadiyah Yogyakarta

Jalan Brawijaya, Tamantirto, Kasihan,

Yogyakarta, 55183, Indonesia

email: lelijokosuryono@yahoo.com

anggriani75@yahoo.co.id

\begin{abstract}
Financial Services Authority Regulation Number 19/POJK.03/2014 concerning Financial Services Without Offices In the Context of Inclusive Finance, the Financial Services Authority in collaboration with the Banking sector makes services sell well. In this study as clever behavior is Bank Central Asia, which is one of the banks that conducts Officeless Financial Services, because it needs to serve people in remote areas, it is necessary to know the definition of clever service in order to know how the legal position of Third Parties in managing smart services still unclear, especially the legal status of the Third Party as a liaison between the bank and the customer. The purpose of the study is to examine and analyze the legal standing of third parties in financial services without offices. This research is a normative legal research that examines the principles, legal concepts and legislation related to the legal position of third parties in the provision of financial services without offices. The conclusion of this study is that Officeless Financial Services is an activity of providing banking services and/or other financial services carried out not through office networks and legal relations of the parties based on cooperation agreements and internal circulars. The legal position of third parties is as a bank liaison with customers (agents) and an extension of the bank (partner), where in each implementation there are rights and obligations that must be fulfilled in order to achieve the implementation of salable services.
\end{abstract}

Keywords: Legal status, Third Party, Financial Services.

\section{ABSTRAK}

Peraturan Otoritas Jasa Keuangan Nomor 19/POJK.03/2014 tentang Layanan Keuangan Tanpa Kantor Dalam Rangka Keuangan Inklusif, Otoritas Jasa Keuangan bekerjasama dengan pihak Perbankan membuat layanan laku pandai. Dalam penelitian ini sebagai laku pandai adalah Bank Central Asia yaitu salah satu perbankan yang melakukan Layanan Keuangan Tanpa Kantor, karena perlu melayani masyarakat yang berada di daerah pelosok, maka perlu diketahui definisi layanan laku pandai supaya tahu bagaimana kedudukan hukum Pihak Ketiga dalam penyelenggaraan layanan laku pandai masih belum jelas, terutama status hukum Pihak Ketiga sebagai penghubung antara bank dengan nasabah. Tujuan penelitian adalah untuk mengkaji dan menganalisis kedudukan hukum pihak ketiga dalam layanan 
keuangan tanpa kantor. Penelitian ini merupakan penelitian hukum normatif yang mengkaji asas-asas, konsep-konsep hukum serta peraturan perundangundangan yang terkait dengan kedudukan hukum pihak ketiga dalam penyelenggaraan layanan keuangan tanpa kantor. Kesimpulan penelitian ini adalah Layanan Keuangan Tanpa Kantor adalah kegiatan menyediakan layanan perbankan dan/atau layanan keuangan lainnya yang dilakukan tidak melalui jaringan kantor dan hubungan hukum para pihak berdasar pada perjanjian kerjasama serta surat edaran internal. Kedudukan hukum pihak ketiga adalah sebagai penghubung bank dengan nasabah (agen) dan perpanjangan tangan pihak bank (mitra), dimana dalam setiap penyelenggaraan terdapat hak dan kewajiban yang harus dipenuhi demi tercapainya penyelenggaraan layanan laku.

Kata Kunci: Kedudukan hukum, Pihak Ketiga, Layanan Keuangan.

\section{PENDAHULUAN}

Layanan Keuangan Tanpa Kantor merupakan layanan yang diberikan oleh industri perbankan dan industri jasa keuangan lainnya dalam mendukung terwujudnya keuangan inklusif yang sejalan dengan yang dicanangkan oleh Pemerintah. Penyelenggaraan Layanan Keuangan Tanpa Kantor ini diatur dalam Peraturan Otoritas Jasa Keuangan Nomor 19/POJK.03/2014 tentang Layanan Keuangan Tanpa Kantor Dalam Rangka Keuangan Inklusif. Namun dalam peraturan tersebut belum dijelaskan bagaimana kedudukan hukum pihak ketiga atau agen. Agen adalah pihak yang bekerjasama dengan Bank penyelenggara Laku Pandai yang menjadi kepanjangan tangan Bank untuk menyediakan layanan perbankan kepada masyarakat dalam rangka keuangan inklusif sesuai yang diperjanjikan. Sejauh mana tanggung jawab yang dibebankan terhadap kedudukan Laku pandai.

Hal tersebut menjadi penting karena laku pandai adalah sebagai pihak ketiga bertanggung jawab memegang data nasabah dengan mengatas namakan nama bank penyelenggara. Dimana Bank sendiri adalah lembaga keuangan yang menjadi tempat bagi orang perseorangan, badan-badan usaha swasta, badan-badan usaha milik negara, bahkan lembagalembaga pemerintahan menyimpan dana-dana yang dimilikinya (Hermansyah, 2013:7), yang harus dapat berfungsi untuk melayani masyarakat dalam bidang perbankan. Perbankan yang didasarkan pada demokrasi ekonomi mempunyai arti bahwa masyarakat harus memegang peranan aktif dalam kegiatan perbankan, sedangkan pemerintah termasuk dalam hal ini Bank Indonesia dan otoritas jasa keuangan bertindak memberikan arahan dan bimbingan terhadap pertumbuhan dunia perbankan sekaligus menciptakan iklim yang sehat bagi perkembangannya (Muhammad Djumhana, 2012:3). Sedangkan menurut Kasmir dalam bukunya DasarDasar Perbankan mengemukakan bahwa fungsi bank sebagai lembaga perantara keuangan antara masyarakat yang kelebihan dana dengan masyarakat yang kekurangan dana (Kasmir, 2015: 4). Perbankan dalam melayani masyarakat dengan keterbatasannya tidak dapat melayani masyarakat secara keseluruhan terutama yang berada di daerah terpecil, sehingga dengan demikian, layanan laku pandai memiliki peranan penting, karena layanan ini merupakan layanan yang disediakan oleh bank sebagai penyedia jasa keuangan yang mendukung rencana pemerintah dalam rangka keuangan inklusif.

\section{RUMUSAN MASALAH}

Dari uraian diatas dapat dirumuskan masalah penelitian sebagai berikut:

a. Apakah yang dimaksud dengan Layanan Keuangan Tanpa Kantor?

b. Bagaimana kedudukan hukum Pihak Ketiga dalam penyelenggaraan Layanan Keuangan Tanpa Kantor?

\section{METODE PENELITIAN}

Untuk mendapatkan bahan penelitian maka penelitian akan dilakukan dengan studi pustaka yang 
mengkaji bahan hukum (Mukti dan Yulianto, 2010:186). Bahan hukum sebagai bahan penelitian diambil dari bahan kepustakaan yang berupa bahan hukum primer, bahan hukum sekunder, dan bahan hukum tersier (Mukti dan Yulianto, 2010, 317).

A. Bahan Hukum Primer, merupakan bahan pustaka yang berisikan peraturan perundangundangan yang terdiri dari:

a. Undang-Undang Nomor 10 Tahun 1998 tentang Perubahan Atas Undang-Undang Nomor 7 Tahun 1992 tentang Perbankan.

b. Peraturan Otoritas Jasa Keuangan Nomor 19/POJK.03/2014 tentang Layanan Keuangan Tanpa Kantor Dalam Rangka Keuangan Inklusif.

c. Peraturan perundang-undangan lainnya yang terkait dengan objek penelitian.

B. Bahan Hukum Sekunder, yaitu bahan-bahan yang erat kaitannya dengan bahan hukum primer, dan dapat membantu untuk proses analisis (Mukti dan Yulianto, 2010:318), yaitu:

a. Buku-buku ilmiah yang terkait.

b. Hasil penelitian terkait.

c. Jurnal-jurnal dan literature yang terkait.

d. Doktrin, pendapat dan kesaksian dari ahli perbankan baik yang tertulis maupun tidak tertulis.

C. Bahan Hukum Tersier, yaitu:

a. Kamus hukum.

b. Kamus besar bahasa Indonesia.

c. Ensiklopedi.

d. Dokumen tentang layanan keuangan tanpa kantor.

Bahan hukum primer, sekunder dan tersier akan diperoleh melalui studi kepustakaan dengan cara menghimpun semua peraturan perundang-undangan, dokumen-dokumen hukum dan buku-buku serta jurnal ilmiah yang berkaitan dengan permasalahan (Mukti dan Yulianto, 2010:319). Dalam penelitian ini pengumpulan data juga dilakukan dengan cara wawancara dan menggali informasi praktisi perbankan yakni dengan bank penyelenggara layanan keuangan tanpa kantor.

Data-data umum, asas-asas hukum, doktrin dan peraturan perundang-undangan dirangkai secara sistematis sebagai susunan fakta-fakta hukum untuk mengkaji dan menganalisis kedudukan hukum pihak ketiga dalam layanan keuangan tanpa kantor. Analisis dilakukan dengan memaparkan dan menjelaskan atas subjek dan objek penelitian sesuai dengan studi kepustakaan dan wawancara (Mukti dan Yulianto, 2010:183).

Dalam hal ini wawancara dilakukan dengan Nur Nugroho, Bidang Hukum Bank Central Asia Kantor Cabang Utama Yogyakarta, dalam wawancara internal oleh Andrean Zige tentang Tanggungjawab Bank Central Asia Kantor Cabang Utama Yogyakarta Terhadap Nasabah dalam Penyelenggaraan Produk Layanan Laku, 29 Desember 2017.

\section{HASIL PENELITIAN DAN ANALISIS}

\section{A. Layanan Keuangan Tanpa Kantor}

Berdasarkan ketentuan Pasal 1 angka 3 Peraturan Otoritas Jasa Keuangan Nomor 19 Tahun 2014 tentang Layanan Keuangan Tanpa Kantor Dalam Rangka Keuangan Inklusif yang dimaksud dengan Layanan Keuangan Tanpa Kantor Dalam Rangka Keuangan Inklusif yang selanjutnya disebut Laku Pandai yang artinya adalah kegiatan menyediakan layanan perbankan dan/atau layanan keuangan lainnya yang dilakukan tidak melalui jaringan kantor, namun melalui kerjasama dengan pihak lain dan perlu didukung dengan penggunaan sarana teknologi informasi.

\section{Macam-Macam Produk}

Layanan keuangan inklusif di Indonesia, diselenggarakan oleh bank penyelenggara dan dijalankan oleh agen yang bekerjasama dengan bank penyelenggara. Agen memegang peranan penting dalam pelaksanaan Layanan Keuangan Tanpa Kantor (Laku Pandai) guna tercapainya keuangan inklusif yang memudahkan masyarakat menggunaan jasa 
keuangan. Agen yang menjadi pelaksana Laku Pandai harus mempunyai kompetensi yang tinggi agar strategi keuangan inklusif dapat terjaga dan terlaksana dengan baik.

Menurut Hadad melalui Lutvia Devintasari, keuangan inklusif adalah pemberian akses sebesarbesarnya kepada lembaga keuangan yag ditujukan untuk seluruh lapisan masyarakat. Tujuan dari keuangan inklusif yaitu meniadakan segala bentuk hambatan terhadap akses keuangan yang didukung oleh berbagai infrastruktur yang mendukung (Lutvia devintasari: 2017:2).

Selain melakukan transaksi layanan keuangan, agen juga memiliki tugas lain yang menjadi tujuan Layanan Keuangan Tanpa Kantor Dalam Rangka Keuangan Inklusif atau yang disebut degan Laku Pandai. Hal tersebut adalah edukasi keuangan kepada masyarakat. Tujuannya agar masyarakat menjadi sadar dan memiliki keinginan untuk menggunakan fasilitas jasa keuangan yang ada. Program Laku Pandai atau Layanan Perbankan tanpa kantor merupakan bentuk ekspansi bank dengan investasi berbiaya rendah. Sebagai tahap awal dari rencana 17 bank yang akan menjalankan program ini, bank yang mendapatkan izin dari OJK untuk menjalankan program ini baru ada empat, yakni Bank Central Asia (BCA), Bank Rakyat Indonesia (BRI), Bank Tabungan Pensiunan Negara (BTPN), dan Bank Mandiri. Bank Central Asia (BCA) menjalankan program ini dengan investasi sebesar 10,6 Miliar untuk mempekerjakan 3.000 agen. Keuntungan sistem laku pandai bagi Nasabah (Didik dan Lutfhia, 2017: 62)
a. Lokasi dekat dengan nasabah
b. Mudah dalam melakukan transaksi
c. Tidak perlu antri
d. Fleksibilitas waktu pelayanan

Secara garis besarnya, tugas agen yang tertulis dalm Pasal 19 Ayat (2) Peraturan Otoritas Jasa Keuangan No. 19/POJK.03/2014 Tentang Layanan Keuangan Tanpa Kantor Dalam Rangka Keuangan Inklusif adalah: a. Transaksi terkait tabungan dengan karakteristik BSA, meliputi pembukaan rekening, penyetoran dan penarikan tunai, pemindahbukuan, pembayaran tagihan, transfer dana, pengecekan saldo, dan/atau penutupan rekening.

b. Transaksi terkait kredit atau pembiayaan kepada nasabah mikro meliputi penerimaan dokumen permohonan, penyaluran pencairan, penagihan atau penerimaan pembayaran angsuran dan/atau pelunasan pokok

c. Transaksi terkait tabungan selain tabungan dengan karakteristik BSA meliputi penyetoran dan penarikan tunai, pemindahbukuan, pembayaran, dan/atau transfer dana

d. Transaksi terkait layanan atau jasa keuangan lain sesuai ketentuan yang berlaku.

Agen laku akan di fasilitasi perangkat yang akan menunjang transaksi Laku, untuk selanjutnya perangkat tersebut akan disebut sebagai perangkat agen, dimana melalui perangkat tersebut Agen Laku dapat memulai transaksi yang dapat dilakukan oleh nasabah juga guna melakukan transaksi melalui perangkat agen yang berada di lokasi Agen Laku, dimana ada beberapa transaksi yang dapat dilakukan antara lain:

a. Informasi Saldo

b. Informasi mutase transaksi terakhir

c. Pembukaan rekening Laku

d. Penutupan rekening Laku

e. Setoran

f. Tarik tunai

g. Transfer antar Laku

h. Perubahan PIN

i. Reset PIN

j. Ganti nomor handphone

k. Blokir

1. Buka Blokir

m. Kehilangan total

Tidak semua bank yang beroperasi di Indonesia bisa mengajukan sebagai bank penyelenggara laku pandai berdasarkan Pasal 10 No. 19/POJK.03/2014 
Tentang Layanan Keuangan Tanpa Kantor menyatakan bahwa:

1. Bank yang akan mengajukan permohonan persetujuan menjadi penyelenggara Laku Pandai sebagaimana dimaksud dalam Pasal 3 harus memenuhi persyaratan sebagai berikut:

a. berbadan hukum Indonesia;

b. memiliki peringkat profil risiko, tingkat risiko operasional dan risiko kepatuhan dengan peringkat 1,2 , atau peringkat 3 .

c. memiliki jaringan kantor di Wilayah Indonesia Timur dan/atau provinsi Nusa Tenggara Timur; dan

d. telah memiliki infrastruktur pendukung untuk menyediakan layanan transaksi elektronik bagi nasabah Bank berupa:

1) Short Message Service (SMS) banking atau mobile banking, dan

2) Internet banking atau host to host.

2. Otoritas Jasa Keuangan dapat melakukan evaluasi secara berkala terkait persyaratan wilayah jaringan kantor Bank sebagaimana dimaksud pada ayat (1) huruf c.

Dalam peraturannya Bank penyelenggara Laku Pandai hanya dapat bekerjasama dengan Agen perorangan yang belum bekerjasama dengan Bank lain. Dan Agen melakukan kewajibannya sesuai dengan perjanjian yang dilaksanakan antara Agen dengan pihak bank. Berdasarkan ketentuan Pasal 19 Peraturan Otoritas Jasa Keuangan Nomor 19/POJK.03/2014 tentang Layanan Keuangan Tanpa Kantor Dalam Rangka Keuangan Inklusif,dalam penyelenggaraan Laku Pandai, Bank penyelenggara hanya dapat melakukan kerjasama dengan Agen yang berkedudukan di lokasi dalam kota atau kabupaten yang sama dengan lokasi jaringan kantor Bank.

Dalam ketentuan Pasal 4 Peraturan Otoritas Jasa Keuangan Nomor 19 Tahun 2014 tentang Layanan Keuangan Tanpa Kantor Dalam Rangka Keuangan Inklusif Produk yang dapat disediakan oleh Lembaga Jasa Keuangan yang menyelenggarakan Laku Pandai antara lain:
a. Tabungan
b. Kredit atau pembiayaan untuk nasabah mikro
c. Asuransi mikro, dan/atau
d. Produk keuangan lainnya berdasarkan Peraturan Otoritas Jasa Keuangan.

\section{Kerjasama Bank dengan Agen}

Berdasarkan ketentuan Bab IV Peraturan Otoritas Jasa Keuangan Nomor 19 Tahun 2014 tentang Layanan Keuangan Tanpa Kantor Dalam Rangka Keuangan Inklusif Bank penyelenggara Laku Pandai bekerjasama dengan Agen untuk menyediakan produk Bank bagi masyarakat yang belum terlayani jaringan kantor Bank.

\section{B. Kedudukan Pihak Ketiga dalam penyelenggaraan Layanan Keuangan Tanpa Kantor. \\ Sebelum membahas mengenai kedudukan Pihak} ketiga dalam layanan penyelenggaraan Layanan Keuangan Tanpa Kantor, maka kita harus mengetahui terlebih dulu tentang Hubungan hukum antara Bank, Pihak Ketiga dan Nasabah dalam penyelenggaraan Layanan Keuangan Tanpa Kantor

Hubungan hukum adalah hubungan yang terjadi antara subjek hukum yang satu dengan subjek hukum lainnya dalam masyarakat sebagaimana diatur oleh hukum. Hubungan hukum tercermin pada melekatnya hak dan kewajiban masing-masing pihak yang terikat dalam suatu perjanjian ( Ridwan Khairandy, 2013: 247). Hubungan hukum antara prinsipal yaitu bank dengan agen didasarkan pada suatu perjanjian keagenan (Ida dan $M$ Alif, 2017:308). Namun dalam penyelenggaraan layanan laku oleh Bank Central Asia ada juga mitra, dimana mitra tersebut adalah merupakan perpanjangan tangan dari bank, dimana mitra ini disebut sebagai kepanjangan Bank Central Asia dalam menyelenggarakan layanan Laku dimana mitra ini bertugas untuk menyelenggarakan dan menyediakan kebutuhan operasional layanan Laku serta mitra berhubungan dengan agen Laku sesuai ketentuan 
perjanjian penyelenggaraan layanan Laku. Perjanjian keagenan yaitu perjanjian antara seorang prinsipal dengan seorang perantara dimana seorang perantara mengikatkan diri kepada prinsipal untuk melakukan perbuatan hukum tertentu bagi kepentingan prinsipal (Ida dan M Alif, 2017:308).

Dalam hal ini, prinsipal memberikan pula kewenangan kepada perantara untuk mengadakan perjanjian dengan pihak ketiga guna kepentingan prinsipal (Ridwan Khairandy, 2013:248). Dengan demikian maka pihak Mitra dapat melakukan perjanjian dengan Bank Central Asia yang dalam perjanjian tersebut akan mengatur semua hak dan kewajiban dari masing-masing pihak, dengan tetap memperhatikan dan tidak bertentangan dengan peraturan OJK mengenai Layanan Keuangan Tanpa Kantor Dalam Rangka Keuangan Inklusif.

Dalam ketentuan Pasal 1 angka 3 Peraturan Otoritas Jasa Keuangan Nomor 19 Tahun 2014 tentang Layanan Keuangan Tanpa Kantor Dalam Rangka Keuangan Inklusif disebutkan bahwa Layanan Keuangan Tanpa Kantor Dalam Rangka Keuangan Inklusif yang selanjutnya disebut Laku Pandai adalah kegiatan menyediakan layanan perbankan dan/atau layanan keuangan lainnya yang dilakukan tidak melalui jaringan kantor, namun melalui kerjasama dengan pihak lain dan perlu didukung dengan penggunaan sarana teknologi informasi.

Penyelenggaraan pada kenyataannya, masingmasing bank memberikan nama tersendiri untuk layanan keuangan tanpa kantor yang mereka selenggarakan, seperti BCA yang menamai layanan tersebut dengan nama Layanan Laku. Berdasarkan hasil wawancara dengan Nur Nugroho, Bidang Hukum Bank Central Asia Kantor Cabang Utama Yogyakarta, dalam wawancara internal oleh Andrean Zige tentang Tanggungjawab Bank Central Asia Kantor Cabang Utama Yogyakarta Terhadap Nasabah dalam Penyelenggaraan Produk Layanan Laku, 29 Desember 2017, dalam penyelenggaraan layanan Laku terdapat 4 (empat) subjek hukum, yaitu Bank
Central Asia, Mitra, Agen Laku dan Nasabah. Disini, pihak Bank Central Asia sebagai pemilik layanan Laku, Mitra sebagai penyelenggara operasional layanan Laku, pihak agen sebagai penyelenggara layanan sedangkan pihak nasabah sebagai pelanggan layanan. Dasar dari hubungan tersebut adalah perjanjian baku, yaitu formulir aplikasi sebagai agen Laku dan formulir aplikasi sebagai nasabah laku.

Hubungan hukum antara Bank Central Asia dengan Mitra didasari oleh Perjanjian Kerjasama yang dibuat oleh Bank Central Asia selaku pemilik produk layanan Laku dengan Mitra yang berfungsi sebagai pihak yang menyelenggarakan operasional, maka disini Mitra sebagai pihak perantara antara bank dengan agen yang akan menjalankan produk layanan Laku. Hubungan hukum antara Bank Central Asia dengan Agen berdasar pada Perjanjian Kerjasama yang dibuat antara Bank Central Asia selaku penyelenggara produk layanan Laku dengan Agen yang berfungsi sebagai pihak yang menyelenggarakan layanan, artinya menyelenggarakan layanan disini Agen sebagai pihak ketiga antara bank dengan nasabah yang akan menggunakan produk layanan Laku. Hubungan hukum antara Bank Central Asia dengan Nasabah didasari oleh Perjanjian atau Ketentuan Baku yang terdapat di Formulir pendaftaran sebagai nasabah yang dibuat oleh Bank Central Asia selaku pemilik produk layanan Laku Pandai dengan Nasabah sebagai pihak yang menggunakan layanan Laku Pandai. Hubungan hukum antara Mitra dengan agen didasari oleh Perjanjian Kerjasama yang sudah dibuat oleh Bank Central Asia. Hubungan hukum antara Agen dengan Nasabah didasari oleh Perjanjian Kerjasama yang sudah dibuat oleh Bank Central Asia.

Penyelenggaraan layanan keuangan tanpa kantor ditujukan akan kegiatan perbankan dapat menjangkau kalangan masyarakat yang berada di wilayah terpencil. Dalam pelaksanaan layanan keuangan tanpa kantor atau biasa juga dikenal layanan laku , bank bekerjasama dengan pihak ketiga sebagai penghubung antara bank dengan nasabah 
atau biasanya disebut sebagai Agen. Sebagaimana diatur dalam Pasal 1 angka 4 Peraturan Otoritas Jasa Keuangan Nomor 19 Tahun 2014 tentang Layanan Keuangan Tanpa Kantor Dalam Rangka Keuangan Inklusif menyebutkan jika Agen adalah pihak yang bekerjasama dengan Bank penyelenggara Laku Pandai yang menjadi kepanjangan tangan Bank untuk menyediakan layanan perbankan kepada masyarakat dalam rangka keuangan inklusif sesuai yang diperjanjikan.

Layanan Laku di Bank Central Asia diselenggarakan dengan berdasar pada Peraturan Otoritas Jasa Keuangan Nomor 19 Tahun 2014 tentang Layanan Keuangan Tanpa Kantor Dalam Rangka Keuangan Inklusif, Surat Edaran Nomor 29/SE/Pol/2017/Laku /Bank Central Asia serta lembaran Ketentuan-ketentuan Laku PT. Bank Central Asia Tbk. Kedudukan pihak ketiga dalam layanan keuangan tanpa kantor atau kalau di Bank Central Asia disebut layanan laku dapat dianalisis dengan menggunakan peraturan-peraturan tersebut.

\section{SIMPULAN}

Layanan Keuangan Tanpa Kantor Dalam Rangka Keuangan Inklusif yang selanjutnya disebut Laku Pandai yang artinya adalah kegiatan menyediakan layanan perbankan dan/atau layanan keuangan lainnya yang dilakukan tidak melalui jaringan kantor, namun melalui kerjasama dengan pihak lain dan perlu didukung dengan penggunaan sarana teknologi informasi sedemikian berdasarkan Pasal 1 angka 3 Peraturan Otoritas Jasa Keuangan Nomor 19 Tahun 2014 tentang Layanan Keuangan Tanpa Kantor Dalam Rangka Keuangan Inklusif.

Dalam hal ini adalah berdasar perjanjian kerjasama diantara para pihak. Perjanjian kerjasama tersebut mengatur hak dan kewajiban bagi masingmasing pihak yang harus dilaksanakan dan ditaati oleh masing-masing pihak. Dalam penyelenggaraan layanan Laku di Bank Central Asia Kantor Cabang Utama Yogyakarta perantaranya atau pihak ketiganya adalah agen Laku dan mitra.
Kedudukan pihak ketiga dapat dilihat dengan menganalisis peraturan otoritas jasa keuangan yaitu Peraturan Otoritas Jasa Keuangan Nomor 19 Tahun 2014 tentang Layanan Keuangan Tanpa Kantor Dalam Rangka Keuangan Inklusif, dan peraturan internal bank yang berupa Surat Edaran Nomor 29/SE/Pol/2017/Laku/Bank Central Asia, hubungan hukum para pihak dalam penyelenggaraan layanan keuangan tanpa kantor atau disebut Layanan Laku Pandai. Kedudukan hukum pihak ketiga dalam layanan laku adalah sebagai penghubung bank dengan nasabah (agen) dan perpanjangan tangan pihak bank (mitra), dimana dalam setiap penyelenggaraan terdapat hak dan kewajiban yang harus dipenuhi demi tercapainya penyelenggaraan layanan laku.

\section{DAFTAR PUSTAKA}

Buku

Achmad, Yulianto dan Mukti Fajar ND, 2015, Dualisme Penelitian Hukum Normatif $\mathcal{E}$ Empiris, Yogyakarta, Pustaka Pelajar.

Djumhana, Muhammad, 2012, Hukum Perbankan di Indonesia,Bandung, PT Citra Aditya Bakti.

Hermansyah, 2013, Hukum Perbankan Nasional Indonesia, Jakarta, Kencana Prenada Media Group.

Kasmir, 2015, Bank dan Lembaga Keuangan Lainnya, Jakarta, PT Raja Grafindo Persada

Kasmir, 2015, Dasar-Dasar Perbankan, Jakarta, PT. Raja Grafindo Persada,

Khairandy, Ridwan, 2013, Pokok-Pokok Hukum Dagang Indonesia, Yogyakarta, FH UII Press.

\section{Jurnal}

Tandika, Dikdik dan Lutfhia Sevriana, 2017, “Adopsi Terhadap Inovasi: Kajian Konseptual Implementasi Program Laku Pandai Pada Layanan Brilink". Jurnal Manajemen Bisnis Performa, Vol. 14, No.1. 
Rahadiyan, Ida dan M. Alif Akbar Pranagara, 2017, "Bentuk Hubungan Hukum Para Pihak dan Tanggung Jawab Agen dalam Penyelenggaraan Branchless Banking di Infonesia”, Jurnal Hukum Ius Quia Iustum, Vol. 24, No.2.

\section{Tesis}

Devintasari, Lutvia, 2017, "Kontribusi Otoritas Jasa Keuangan Dalam Implementasi Akses Layanan Keuangan Kantor Dalam Rangka Keuangan Inklusif (Laku Pandai) Pada Perbankan Indonesia (Studi Kasus Pada Agen Yang terdaftar di PT. Bank Tabungan Pensiun Negara (Persero) Tbk Surakarta”, Thesis, Universitas Sebelas Maret, Indonesia.

\section{Peraturan Perundang-undangan}

Undang-Undang Nomor 10 Tahun 1998 tentang Perubahan Atas Undang-Undang Nomor 7 Tahun 1992 tentang Perbankan.

Peraturan Otoritas Jasa Keuangan Nomor 19/POJK.03/2014 tentang Layanan Keuangan Tanpa Kantor Dalam Rangka Keuangan Inklusif. 